\title{
Assessment of the Diversity of Leaf Epidermal Traits of Dipcadi Filamentosum Medik Among Different Co-Geographical Regions in Nigeria
}

\author{
K. A. Abdulkareem ${ }^{1}$ and O. T. Mustapha \\ Received: $29^{\text {th }}$ August 2015 / Accepted: 27th January 2016
}

\begin{abstract}
This study was conducted to disentangle the influence of environmental variables on the spatial patterns in leaf epidermal traits (i.e. stomatal occurrence, stomatal traits and epidermal cells) in some morphologically different populations of Dipcadi filamentosumMedik in Nigeria. The stomatal occurrence and the stomatal length (SL), stomatal width (SW), stomatal size (SS), stomatal density (SD) and stomatal index (SI) of 13 ecotypes of D. filamentosum from 11 locations in Nigeria were studied. All the populations were amphistomatous with $100 \%$ tetracytic stomatal complex type. The epidermal cells were rectangular in shape with straight to curve anticlinal cell wall pattern. Contrarily, the species from the Northern eco-geographical location had larger SS, higher SD, longer SL, higher SI and wider SW and higher epidermal cell density than those from the Southern eco-geographical location where there is higher annual rainfall and lower temperature. Temperature and rainfall affected SD, SI and SL, SS and SW whereas the epidermal cells and anticlinal cell walls were not affected. Variations were observed within and between the populations from the 4 eco-geographical locations. The variables observed among the 4 ecogeographical populations of D.filamentosumshowed that effects of environmental factors are partial on the leaf epidermal traits of the plant. The evidences from the studied characters are good taxonomic features or indicators hence they can be used to separate them to different species.
\end{abstract}

Keywords: amphistomatic, dipcadi filamentosum, eco-geographical, epidermal traits, stomata.

\section{INTRODUCTION}

Stomata play a pivotal role in the regulation of gas exchange in flowering plants and are distributed throughout the aerial epidermis. In leaves, the pattern of stomatal distribution is highly variable between species but is regulated by a mechanism that maintains a minimum of one cell spacing between stomata. The environment also has significant effects on stomatal development. In a number of species both light intensity and $\mathrm{CO}_{2}$ concentrations have been shown to influence the frequency at which stomata develop on leaves. Long-distance signalling mechanisms have been implicated in these environmental responses with the conditions sensed by mature leaves determining the stomatal frequency in developing leaves. Thus, changes in the environment appear to act by modulating the developmental and patterning pathways to determine stomatal frequency (Casson and Gray 2008).

Dipcadi is a genus of bulbous flowering plants in the division Tracheophyta, class Liliopsida, order Asparagales, family Asparagaceae and subfamily Ornithogaloideae (also treated as the family Hyacinthaceae, subfamily Scilloideae) (Stevens 2001). It is widely distributed, occurring in southern Europe, most of Africa and the

${ }^{1}$ Department of Plant Biology, Faculty of Life Sciences, University of Ilorin, P.O. BOX 1515 Ilorin, Kwara State, 
Middle East through to the Indian subcontinent (Stevens 2001). Species of Dipcadi grow from bulbs and are 'onion like' (Allium spp). It is a perennial, deciduous, small bulbous herb. Bulb ovoid to globose, sometimes forming a neck, firm with the outer tunic thin. It sometimes forms runners or bulbils. It has many thin roots, leaves one to many, usually contemporary with flowers; basal; straight or spirally twisted. The flowers are bell-shaped or tubular (Manning et al., 2004).Stamens, which are enclosed within the flower, are joined to the tube formed by the tepals and have flat filaments. The black seeds are in the shape of a disc or a flattened globe (Grey-Wilson et al., 1981; Ghazanfar, 1996).

According to Jones (1998), features of leaf surface anatomy are a complex of traits defined by stomatal characteristics (density, frequency and position) and epidermal characteristics (density, shape and size of epidermal cells). Sagaram et al., (2007) opined that leaf anatomic characteristics because of their importance in regulation of water loss and water use efficiency could be a useful traits for cultivar development, particularly in selection for drought tolerance. In Nigeria the northern zones have little annual rainfall with higher temperature than the southern zones. The population under study were collected from different zones. The aim of this study, therefore, is to disentangle the influence of environmental factors such as rainfall and temperature on the spatial patterns in stomatal occurrence and stomatal traits in the populations of Dipcadi filamentosum collected from four (4) ecological and geographical locations in Nigeria. This plant was studied because though found wild all over the country, its anatomy is understudied in Nigeria.

\section{MATERIALS AND METHODS}

\section{Study materials}

Whole plants comprising the bulb and the leaves of thirteen (13) populations of D. filamentosum were collected from eleven (11) sites in eight (8) states covering four (4) eco-geographical zones in Nigeria. The average rainfall and temperature of the collection places are shown in Table 01 . The sample representatives were transplanted into 5 litre capacity buckets filled with sandyloam soil and maintained with three replicates at the botanical garden, University of Ilorin, Ilorin, Kwara State, Nigeria (latitude N 08 28' 53.3", E $04^{0} 40$ ' 28.9) in 2012. The average monthly rainfall and temperature of Ilorin from July, 2012 to Dec, 2013 were obtained from the Nigeria Meteorological Agency (NIMET), Abuja, Nigeria.

Table 01: Population of Dipcadi filamentosum collected from various sites in Nigeria

\begin{tabular}{lccccc}
\hline $\begin{array}{c}\text { Geographical } \\
\text { location }\end{array}$ & Place of collection & $\begin{array}{c}\text { State of } \\
\text { collection }\end{array}$ & $\begin{array}{c}* \text { Annual rainfall } \\
(\mathrm{mm})\end{array}$ & $\begin{array}{c}\text { *Mean temp } \\
\left({ }^{\circ} \mathrm{C}\right)\end{array}$ & Soil type \\
\hline South Western & Ekiti & Ekiti & $1,605.40$ & 26.87 & Sandy loam \\
& Ogun & Ogun & $1,126.05$ & 25.05 & $\begin{array}{c}\text { Sandy loam } \\
\text { North East }\end{array}$ \\
Oyo & Oyo & $1,318.10$ & 26.61 & loamy \\
& Maiduguri & Borno & 745.70 & 28.86 & Sand \\
North Central & Yobe & Yobe & 696.60 & 29.70 & Sand \\
& Sobi & Kwara & $1,046.30$ & 26.35 & Sandy \\
& Tanke & Kwara & $1,046.30$ & 26.35 & Sharp sands \\
& Unilorin & Kwara & $1,046.30$ & 26.35 & Sandy loam \\
& Kaiama (small) & Kwara & $1,046.30$ & 26.35 & Loamy \\
& Kaiama (big) & Kwara & $1,046.30$ & 26.35 & Clay loamy \\
& Kaiama (medium) & Kwara & $1,046.30$ & 26.35 & Loamy \\
North West & Kabba & Kogi & NA & NA & Loamy clay \\
& Katsina & Katsina & 527.5 & 27.28 & Sandy loam \\
\hline
\end{tabular}

"Average rainfall and mean temperature of the collection locations for 2012 as provided by the Nigeria Meteorological Agency (NIMET). $\mathrm{NA}=$ Rainfall and temperature information not available . 


\section{Isolation of leaf epidermal layer}

A portion of mature leaf (12 weeks after transplant) close to the midrib of each of the 13 populations in 3 replicates were thinly peeled and macerated. Each of the samples was stained in freshly prepared $1 \%$ aqueous solution of safranin for 5 minutes. Excess stain was rinsed off the surface with clean water. The stained surfaces were placed on slides and a drop of glycerine added to the stained surface, then covered with a cover slip. Observations were made using microscope (Olympus, USA) to determine epidermal cell type and size, stomatal complex type and size, stomatal index and stomatal density. All observations were recorded.

\section{Determination of frequency of stomatal complex types}

Using the field of view at X40 objective as quadrant the numbers of subsidiary cells per stoma were recorded and the frequency of different complex type present in each specimen were determined as percentage occurrence of such complex type based on all occurrences (Obiremi and Oladele 2001). Terminologies for naming stomatal complex type followed those of Dilcher (1974) and Metcalfe and Chalk (1988).

\section{Determination of stomatal density and stomatal index}

The stomatal density (SD) was determined as number of stomatal per square millimeter (Stace, 1965).

$\mathrm{SD}=$ Number of stomata in $0.152 \mathrm{~mm}^{2}$ field of view.

Stomatal indexes (SI) were determined as follow:

$\mathrm{SI}=\mathrm{S} / \mathrm{E}+\mathrm{S} \times 100$

Where: $\mathrm{SI}=$ stomata index

$\mathrm{S}=$ number of stomata per square millimeter

$\mathrm{E}=$ number of ordinary epidermal cell per square millimeter.

\section{Determination of stomatal size (SS)}

The mean stomatal sizes of the populations were determined by measuring length and breadth of guard cells of 35 stomata per view multiplied by Franco's constant using an eye piece micrometer as described by Franco (1939) and Wilkinson (1979).

$\mathrm{SS}=\mathrm{L} \times \mathrm{B} \times \mathrm{K}$

Where $\mathrm{L}=$ length

$\mathrm{B}=$ Breadth

$\mathrm{K}=$ Franco's constant $=0.78524$

\section{Determination of epidermal cell size}

Epidermal cell sizes were determined as product of length and breadth of cell using eye piece micrometre, and sample size of 35 cells were used.

\section{Statistical analysis}

Data generated were analysed using analysis of variance (ANOVA), Duncan Multiple Range Test (DMRT) to separate the means and PAST (Paleontological Statistic), version 3.5 to generate dendrogram. Abaxial and Adaxial parameters were analysed separately and collectively. Results are presented in tables and figures.

\section{RESULTS}

The monthly temperature and rainfall in Ilorin where the experimental field was located from July 2012 when the field study commenced to Dec. 2013 is shown in Figure 01a and b. Highest rainfall $(230.0 \mathrm{~mm})$ for 2012 was recorded in September and the least $(8.7 \mathrm{~mm})$ in November, which had the highest temperature $\left(27.3^{\circ} \mathrm{C}\right)$ while August of the same year was the coolest month. In 2013, rainfall peak of $266.5 \mathrm{~mm}$ was recorded in September while little precipitation of $4.8 \mathrm{~mm}$ was recorded in January. The rainfall pattern for 2013 had bimodal peak at the months of April and Sept (Figure 1b). In the 
same period, March was the hottest month with mean temperature of $29.0^{\circ} \mathrm{C}$ and August was the coolest with mean temperature of $24.1^{\circ} \mathrm{C}$

Epidermal cells and the anticlinal cell were rectangular in shape, straight to curve respectively in all the populations of the $D$. filamentosum studied. Higher epidermal cell density occurred in adaxial surface of Kabba populations while lower epidermal cell density occurred in adaxial surface of Yobe populations (Table 02 and 03). The photomicrograph of the stomatal structure characters in different populations is shown in Figure 02. The stomatal complex type is homogenous with only tetracytic type in all the studied populations with $100 \%$ occurrence in both abaxial and adaxial leaf surfaces. This, therefore, means that the leaves in all the populations are amphistomatic (i.e. having stomata on both abaxial and adaxial leaf surfaces). The two (2) types of amphistomatic situations are observed in these populations namely epiamphistomatic (i.e. having more stomata in upper/adaxial epidermal surface of leaf than in the lower/abaxial surface) e.g. in Kabba and Tanke populations, and hypoamphistomatic (i.e. having more stomata in lower/abaxial epidermal surface of leaf than in the upper/adaxial surface) as in Ekiti, Katsina, Kaiama, Maiduguri, Ogun, Oyo, Sobi and Yobe populations (Table 02 and 03 ).

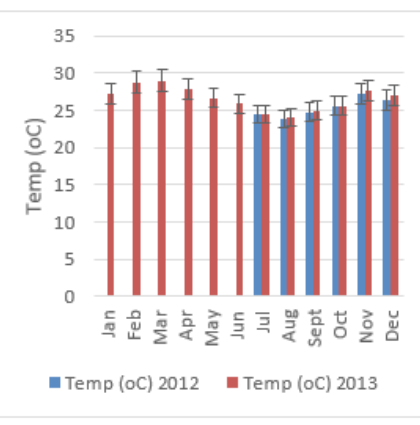

(a)

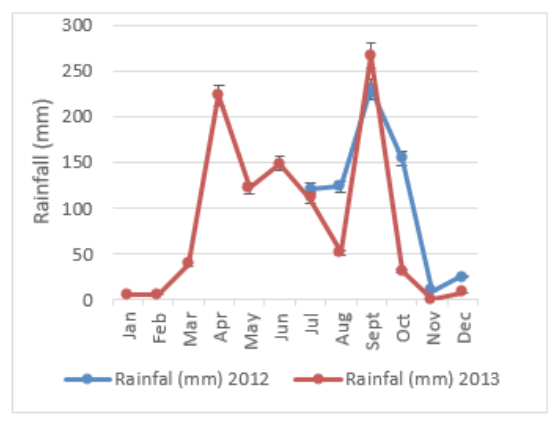

(b)

Figure 01: Showing mean temperature of Ilorin from July 2012 to Dec, 2013 (b) Average monthly rainfall from July, 2012 to Dec, 2013.

Table 02: Abaxial Stomatal features of populations of Dipcadi filamentosum collected from various locations

\begin{tabular}{|c|c|c|c|c|c|c|}
\hline \multirow{2}{*}{ Population } & \multicolumn{5}{|c|}{ Stomata } & \multirow{2}{*}{$\begin{array}{l}\text { Epidermal cell } \\
\text { density }\left(\mathrm{mm}^{2}\right)\end{array}$} \\
\hline & Density $\left(\mathrm{mm}^{2}\right)$ & Length $(\mu \mathrm{m})$ & Width $(\mu \mathrm{m})$ & Size $(\mu \mathrm{m})$ & Index (\%) & \\
\hline Ekiti & $11.60 \pm 0.25^{a b}$ & $19.20 \pm 0.86^{b}$ & $11.00 \pm 0.32$ abcde & $165.84 \pm 8.93^{\mathrm{cd}}$ & $61.62 \pm 2.83^{a b c d}$ & $8.00 \pm 0.71^{\mathrm{gh}}$ \\
\hline Katsina & $7.80 \pm 1.36^{\mathrm{cdefg}}$ & $13.20 \pm 0.37^{\mathrm{abc}}$ & $9.00 \pm 0.45^{\mathrm{defg}}$ & $93.59 \pm 6.49 \mathrm{def}$ & $55.48 \pm 6.87^{\mathrm{bcd}}$ & $6.00 \pm 0.84^{\mathrm{gh}}$ \\
\hline Kaiama big & $13.20 \pm 0.58^{\mathrm{a}}$ & $13.20 \pm 0.58 \mathrm{abc}$ & $7.60 \pm 0.93^{\mathrm{g}}$ & $78.99 \pm 10.86^{\text {ef }}$ & $20.83 \pm 2.29^{\mathrm{fg}}$ & $52.20 \pm 5.29^{a}$ \\
\hline Kaiama medium & $10.00 \pm 1.05^{\mathrm{bc}}$ & $13.00 \pm 0.55^{\mathrm{abc}}$ & $8.60 \pm 0.40^{\mathrm{defg}}$ & $88.00 \pm 3.83 \mathrm{def}$ & $19.68 \pm 1.13^{\mathrm{g}}$ & $43.60 \pm 3.23 \mathrm{abc}$ \\
\hline Kaiama small & $7.00 \pm 0.32^{\text {cdefgh }}$ & $15.80 \pm 1.07^{\mathrm{cdef}}$ & $10.20 \pm 0.49$ bcdefg & $126.72 \pm 8.32^{b c}$ & $25.79 \pm 1.17 \mathrm{fg}$ & $21.80 \pm 1.02$ ef \\
\hline Kabba & $3.00 \pm 0.32^{\mathrm{i}}$ & $21.40 \pm 0.51^{\mathrm{a}}$ & $11.80 \pm 0.58^{a b c}$ & $199.55 \pm 11.40^{\mathrm{ab}}$ & $8.40 \pm 1.23^{h}$ & $35.80 \pm 2.15^{\mathrm{cd}}$ \\
\hline Maiduguri & $14.00 \pm 0.71^{\mathrm{a}}$ & $20.20 \pm 0.58^{a b}$ & $14.0 \pm 1.05^{\mathrm{a}}$ & $221.00 \pm 15.69 a$ & $52.57 \pm 4.63 \mathrm{~cd}$ & $10.20 \pm 2.01^{\mathrm{gh}}$ \\
\hline Ogun & $11.60 \pm 0.51^{\mathrm{ab}}$ & $14.80 \pm 0.58^{\text {cdef }}$ & $11.20 \pm 0.97$ abcde & $131.66 \pm 13.72 \mathrm{bc}$ & $64.34 \pm 4.12^{a b c}$ & $6.20 \pm 0.97^{\mathrm{gh}}$ \\
\hline Oyo & $6.20 \pm 0.37^{\mathrm{fgh}}$ & $17.20 \pm 0.20^{\mathrm{c}}$ & $12.20 \pm 0.80^{\mathrm{a}}$ & $165.06 \pm 26.95^{\mathrm{cd}}$ & $57.88 \pm 6.69^{a b c d}$ & $4.80 \pm 0.97^{h}$ \\
\hline Sobi & $15.60 \pm 0.81^{\mathrm{abc}}$ & $12.40 \pm 0.25^{\mathrm{c}}$ & $8.60 \pm 0.25 \mathrm{defg}$ & $84.37 \pm 3.72$ ef & $32.09 \pm 1.96^{\text {ef }}$ & $39.20 \pm 5.39 \mathrm{bc}$ \\
\hline Tanke & $9.60 \pm 0.25 \mathrm{bcd}$ & $14.20 \pm 0.80^{\text {fghi }}$ & $9.40 \pm 0.40^{\text {cdefg }}$ & $104.60 \pm 3.40^{\mathrm{cdef}}$ & $24.73 \pm 0.34^{\mathrm{fg}}$ & $29.20 \pm 0.37^{\mathrm{cd}}$ \\
\hline Unilorin & $13.60 \pm 1.14^{\mathrm{a}}$ & $12.8 \pm 0.84^{\mathrm{c}}$ & $11.5 \pm 1.0^{a b c}$ & $115.55 \pm 1.98^{\text {cde }}$ & $35.21 \pm 4.19^{\text {ef }}$ & $25.2 \pm 3.11^{\mathrm{de}}$ \\
\hline Yobe & $8.40 \pm 0.40^{\text {cdef }}$ & $16.80 \pm 0.49^{c}$ & $9.60 \pm 0.51^{\text {bcdef }}$ & $127.05 \pm 9.34^{b c}$ & $68.16 \pm 3.72^{b}$ & $3.80 \pm 0.58^{\mathrm{h}}$ \\
\hline
\end{tabular}

Mean followed by different letter(s) along a column are significantly different at 0.05 probability level. 


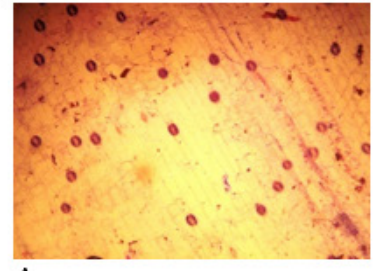

A

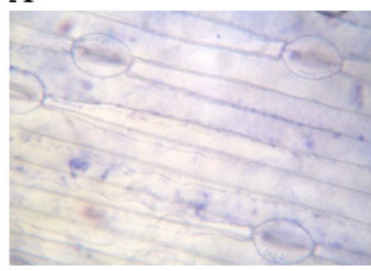

E

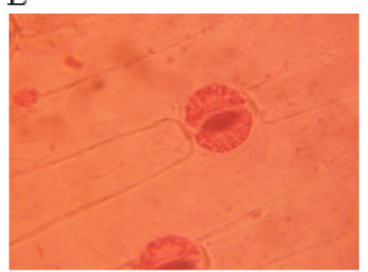

I

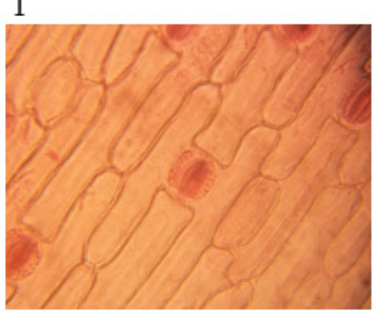

M

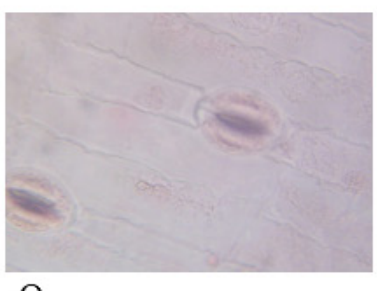

Q

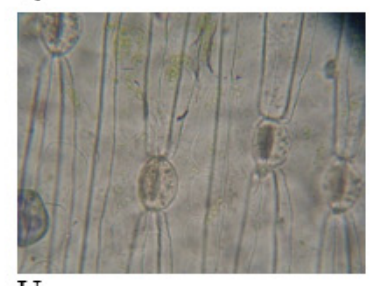

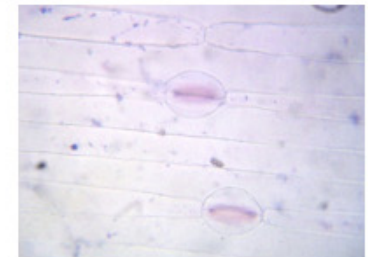

B

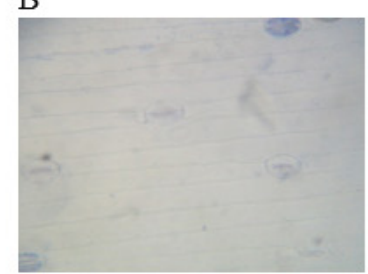

F

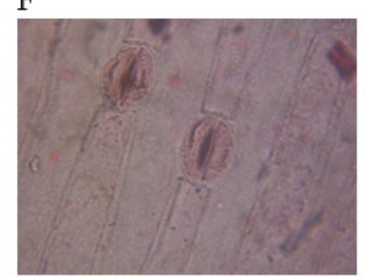

J

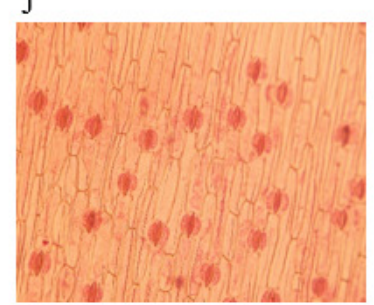

N

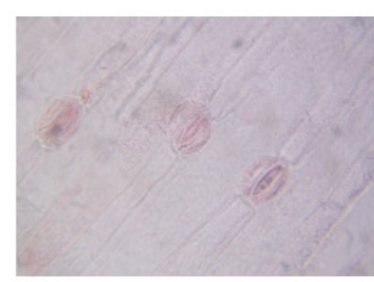

$\mathrm{R}$

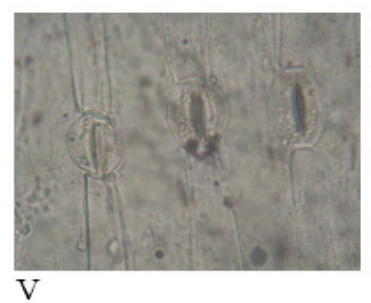

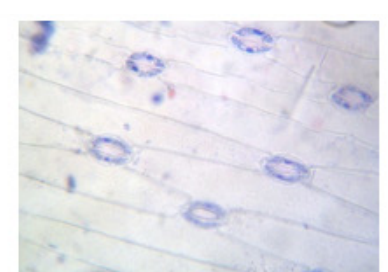

C

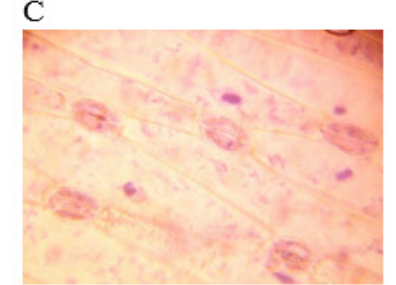

G

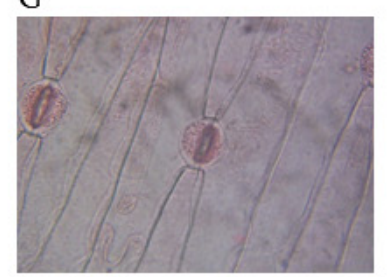

K

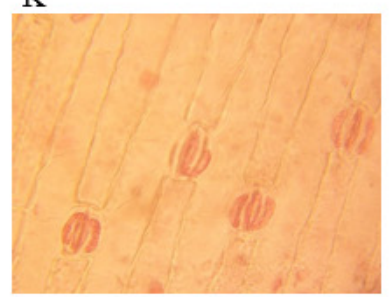

O

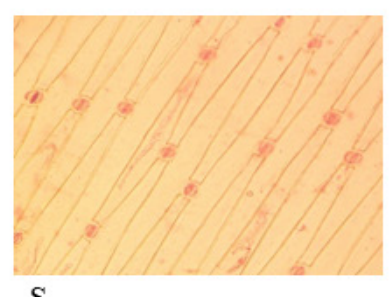

S
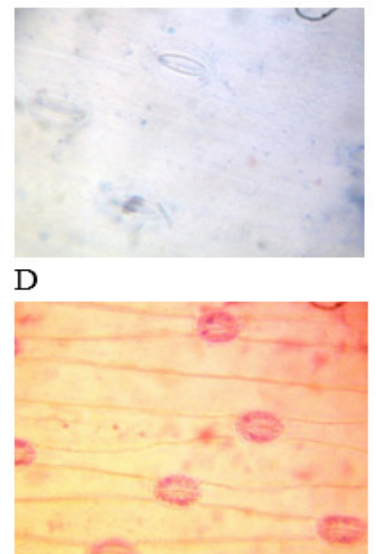

H

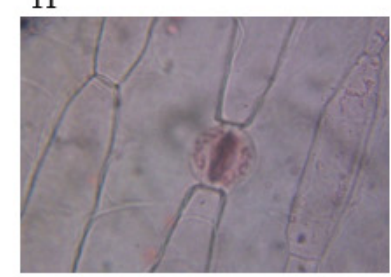

L

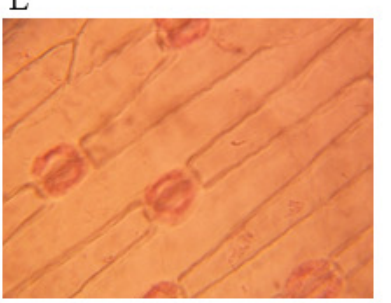

P

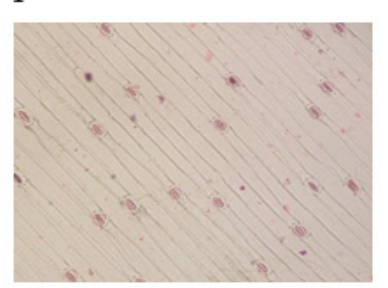

$\mathrm{T}$

Figure 02: Leaf epidermal surface of some populations of Dipcadi filamentosum collected from different locations in Nigeria showing tetracytic stomata (a) Kabba adaxial surface, (b) Kabba abaxial surface, (c) Tanke adaxial surface, (d) Tanke abaxial surface, (e) Kaima medium adaxial surface, (f) Kaima medium abaxial surface, (g) Sobi adaxial surface, (h) Sobi abaxial surface, (i) Ekiti adaxial surface, (j) Ekiti abaxial surface, (k) Katsina adaxial surface, (l) Katsina abaxial surface, (m) Maiduguri adaxial surface, (n) Maiduguri abaxial surface, (o) Ogun adaxial surface, (p) Ogun abaxial surface, (q) Oyo adaxial surface, (r) Oyo abaxial surface, (s) Yobe adaxial surface, (t) Yobe abaxial surface, (u) Yobe adaxial surface, (v) Yobe abaxial surface. $x 600$ 
Table 03: Adaxial Stomatal features of populations of Dipcadi filamentosum collected from various locations

\begin{tabular}{|c|c|c|c|c|c|c|}
\hline \multirow{2}{*}{ Population } & \multicolumn{5}{|c|}{ Stomatal } & \multirow{2}{*}{$\begin{array}{l}\text { Epidermal cel } \\
\text { density }\left(\mathrm{mm}^{2}\right)\end{array}$} \\
\hline & Density $\left(\mathrm{mm}^{2}\right)$ & Length $(\mu \mathrm{m})$ & Width $(\mu \mathrm{m})$ & Size $(\mu \mathrm{m})$ & Index $(\%)$ & \\
\hline Ekiti & $11.60 \pm 0.25$ ab & $19.20 \pm 0.86^{b}$ & $11.00 \pm 0.32$ abcde & $165.84 \pm 8.93^{\text {cd }}$ & $61.62 \pm 2.83$ abcd & $8.00 \pm 0.71^{\mathrm{gh}}$ \\
\hline Ekiti & $8.00 \pm 0.95^{\text {cdefg }}$ & $14.40 \pm 0.25^{\mathrm{fgh}}$ & $13.60 \pm 0.24 \mathrm{ab}$ & $153.91 \pm 4.92 \mathrm{de}$ & $66.67 \pm 5.38 \mathrm{bc}$ & $4.00 \pm 0.71^{\mathrm{h}}$ \\
\hline Katsina & $6.20 \pm 1.07^{\mathrm{fgh}}$ & $12.80 \pm 1.32^{\mathrm{bc}}$ & $11.40 \pm 0.40$ abcd & $116.21 \pm 15.03^{\mathrm{cd}}$ & $50.18 \pm 7.22^{\mathrm{d}}$ & $6.00 \pm 0.84 \mathrm{gh}$ \\
\hline Kaiama big & $16.60 \pm 0.81^{a}$ & $15.40 \pm 0.51^{\text {cdef }}$ & $8.80 \pm 0.02^{\text {defg }}$ & $106.48 \pm 4.67^{\text {cdef }}$ & $21.92 \pm 1.09^{\mathrm{fg}}$ & $59.40 \pm 2.79^{\mathrm{a}}$ \\
\hline Kaiama medium & $9.80 \pm 0.97$ bcd & $14.40 \pm 0.25^{\text {fgh }}$ & $8.40 \pm 0.24$ efg & $95.59 \pm 3.46$ def & $17.19 \pm 0.71^{\mathrm{gh}}$ & $47.40 \pm 5.07 \mathrm{ab}$ \\
\hline Kaiama small & $8.00 \pm 0.45^{\text {cdefg }}$ & $16.60 \pm 0.51$ & $10.40 \pm 0.68$ abcedef & $135.80 \pm 8.10 \mathrm{abc}$ & $16.83 \pm 0.67 \mathrm{gh}$ & $41.60 \pm 2.71^{\mathrm{cd}}$ \\
\hline Kabba & $4.60 \pm 0.40^{\text {hi }}$ & $19.60 \pm 0.68^{\mathrm{b}}$ & $13.60 \pm 1.03 \mathrm{ab}$ & $212.34 \pm 22.60 \mathrm{ab}$ & $20.67 \pm 2.45^{\mathrm{fg}}$ & $18.80 \pm 1.20^{\mathrm{f}}$ \\
\hline Maiduguri & $8.80 \pm 0.49^{\text {cde }}$ & $17.20 \pm 0.37^{\mathrm{c}}$ & $14.20 \pm 0.37^{\mathrm{a}}$ & $192 \pm 6.38 \mathrm{bc}$ & $37.02 \pm 2.83^{\mathrm{e}}$ & $15.20 \pm 1.20^{\mathrm{fg}}$ \\
\hline Ogun & $10.20 \pm 0.20 \mathrm{bc}$ & $16.40 \pm 0.40$ cde & $12.00 \pm 0.32 \mathrm{ab}$ & $154 \pm 5.66 \mathrm{de}$ & $58.89 \pm 3.93$ abcd & $7.60 \pm 1.63$ gh \\
\hline Оуо & $5.60 \pm 0.40^{\mathrm{gh}}$ & $15.60 \pm 0.40^{\text {cdef }}$ & $12.20 \pm 0.37^{\mathrm{a}}$ & $149.82 \pm 8.06$ & $55.51 \pm 5.33$ bcd & $4.60 \pm 0.68^{h}$ \\
\hline Sobi & $13.6 \pm 1.69^{b c}$ & $14.00 \pm 0.32$ fghi & $10.00 \pm 0.00$ abcde & $110.60 \pm 2.49^{\text {cde }}$ & $22.15 \pm 2.09^{\mathrm{fg}}$ & $47.40 \pm 1.98 \mathrm{ab}$ \\
\hline Tanke & $15.80 \pm 1.36^{\mathrm{ab}}$ & $14.60 \pm 0.25$ efgh & $9.60 \pm 0.24$ bcdef & $109.97 \pm 3.92$ cdef & $22.47 \pm 1.05^{\mathrm{fg}}$ & $56.20 \pm 8.19$ ab \\
\hline Unilorin & $8.80 \pm 0.84^{\text {defg }}$ & $11.6 \pm 1.14^{\mathrm{abc}}$ & $11.2 \pm 1.64$ abcd & $101.14 \pm 1.58^{\text {cdef }}$ & $25.54 \pm 1.03^{\mathrm{fg}}$ & $25.6 \pm 1.40^{\mathrm{ef}}$ \\
\hline Yobe & $7.40 \pm 0.68$ defg & $12.80 \pm 0.37 \mathrm{bc}$ & $7.80 \pm 0.58^{\mathrm{fgS}}$ & $78.68 \pm 7.10^{\mathrm{f}}$ & $80.56 \pm 3.90^{\text {a }}$ & $1.80 \pm 0.37^{\mathrm{h}}$ \\
\hline
\end{tabular}

Mean followed by different letter(s) along a column are significantly different at 0.05 probability level.

There are differences in the stomata features such as stomata density, index and size among populations. Higher stomatal density of $16.60 \mathrm{~mm}^{2}$ was observed in adaxial surface of Kaiama big population, while lower densities of $3.00 \mathrm{~mm}^{2}$ and $4.60 \mathrm{~mm}^{2}$ were in abaxial and $\mathrm{j}$ adaxial leaf surfaces respectively of Kabba populations. The stomatal index was higher $(80.56 \%)$ in abaxial surface of Yobe populations and lower $(8.40 \%)$ in the abaxial surface of Kabba populations. The stomatal length was longer $(21.40 \mu \mathrm{m})$ in abaxial surface of Kabba populations while it was shorter $(12.40 \mu \mathrm{m})$ in abaxial surface of Sobi populations. The stomatal width was wider $(14.20 \mu \mathrm{m})$ in abaxial and adaxial surfaces of Maiduguri populations; but narrower $(7.60 \mu \mathrm{m})$ in abaxial surface of Kabba populations (Table 02 and 03). There are instances of significant differences and nonsignificant differences within and between the populations of $D$. filamentosum from the 4 ecogeographical zones of Nigeria.

The neighbour joining cluster analysis has divided the populations into two (2) groups on the abaxial surface parameters. Populations majorly from the north central eco geographical region are neighbours except for the Kabba population that was joined with Maiduguri. Likewise those from the south - west (Ekiti and Oyo) are joined together by the neighbour joining analysis (Figure 03a). Variations were however observed in the clustering of distant populations (Kabba - Maiduguri and Ogun Yobe) abaxial stomatal characters. In contrast, the adaxial leaf epidermal characters as shown by neighbour joining clustered the populations based on their eco geographical location. However, Kabba population consistently joined to Maiduguri (Figure.03b).

The combination of both the abaxial and adaxial characters in Neighbour Joining analysis has separated the taxa into two main clusters with five groups. The populations from the first group based on the foliar epidermal characters obtained from the study are Ogun and Ekiti adaxial, Oyo adaxial and Oyo abaxial clustered as same and the Katsina abaxial and Yobe adaxial are shown as same based on the the studied characters. 


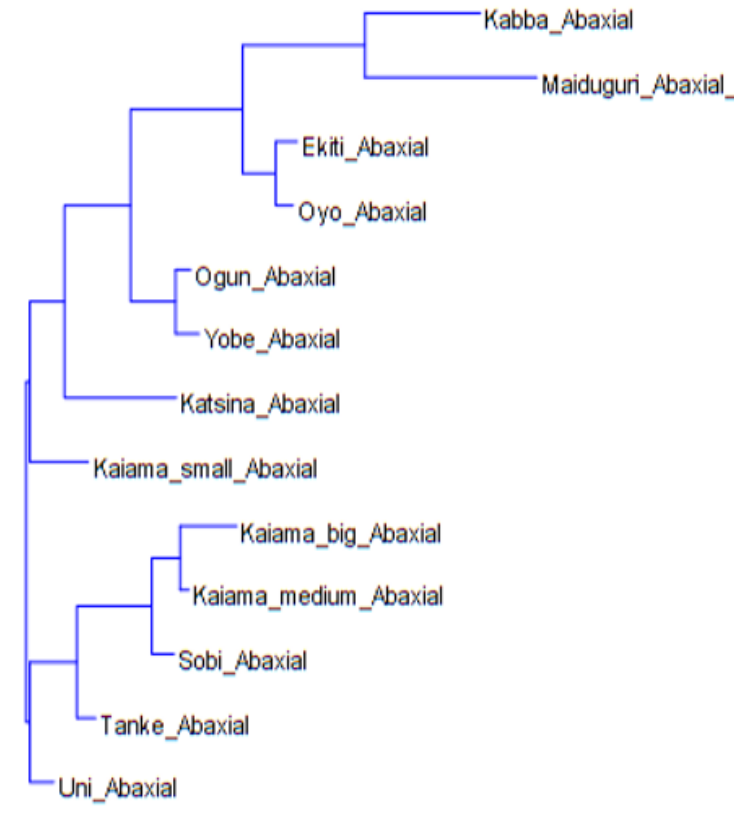

a

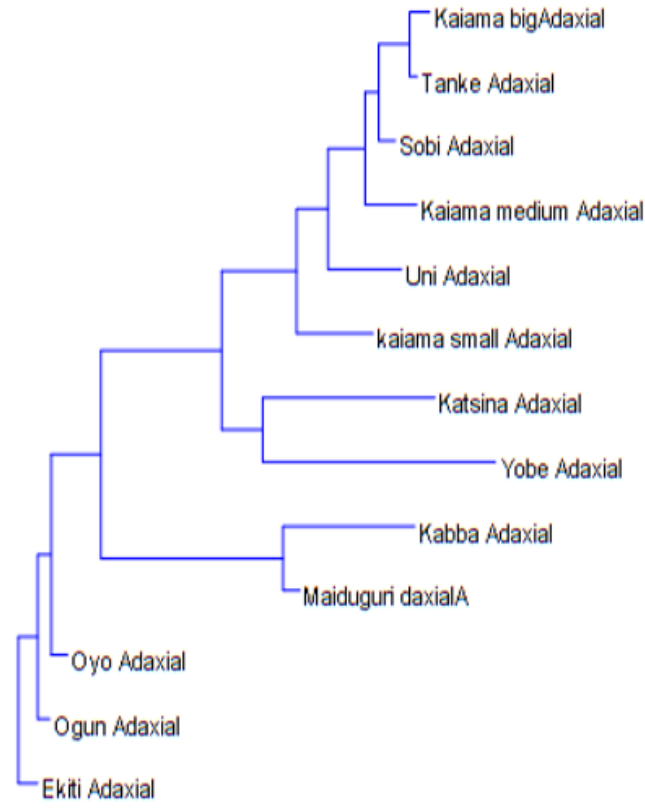

b

Figure 03: Neighbour joining clustering of 13 populations of Dipcadi filamentosum(a) based on Abaxial leaf epidermal characters and (b) based on Adaxial leaf epidermal characters.

Kaiama big, Kaiama medium abaxial and clustered together however the abaxial and Kaiama medium adaxial are clustered together as very close. The populations from Kaiama and Tanke based on their adaxial surfaces are adaxial leaf surface parameters of Tanke and UNI populations have brought the population together as one. Figure 04.

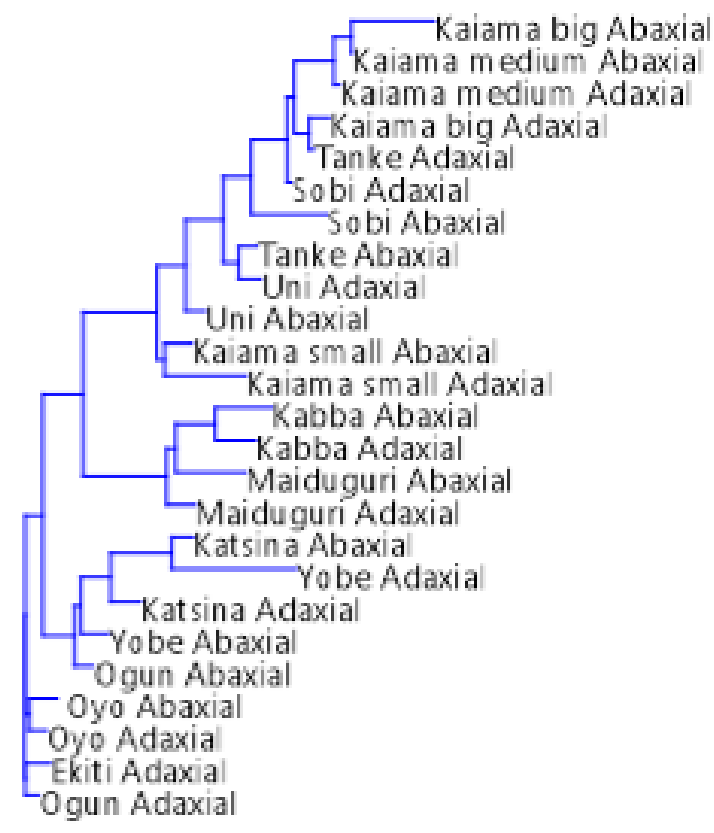

Figure 04: Neighbour joining clustering of 13 populations of Dipcadi filamentosum(a) based on both Abaxial and Adaxial leaf epidermal characters. 


\section{DISCUSSION}

One of the leaf features that respond to variation in environmental factors are stomata. Leaf stomata are the principal means of gas exchange in vascular plants. Environmental factors such as availability of water, temperature, carbon dioxide etc. influences stomata density, index, and size. Changes in several environmental parameters are thought to affect stomata development. Light intensity (Lake et al., 2001), light quality (Schoch et al., 1980), humidity (Serna and Fenoli, 2000), UV-B radiation (Kakani et al., 2003), drought signals (Franks and Farquhar, 2001) and elevated $\mathrm{CO}_{2}$ concentrations (Woodward and Kelly, 1995), have all been shown to affect stomatal density and/or the stomatal and index. In the works of Carr and Carr (1990), Obiremi and Oladele (2001), Oyeleke et al., (2004) and AbdulRahaman and Oladele (2003; 2009), plants with stomata that are endowed with features such as lower stomatal density, lower stomatal index and smaller stomatal size survive environments with little amount of water and higher temperature. This phenomenon was adequately captured by Schoch et al., (1980), when they reported thatwhen sun plants are kept for a whole day in the shade this can cause a decrease in the stomatal index. For shade plants it is shown that a single day of high light intensity during this critical period will cause an increase in the stomatal index. In line with this, stomatal densities have been related to tolerance to abiotic stress conditions, such as drought (Jarvis and Davies, 1998; Van Rensburg et al., 1999) and temperature extremes (Kleinhenz et al., 1995; Nayeem, 1989) as is the case in the northern zones. Results from this study also support the above works, for example, some populations in the Northern parts of Nigeria where there is little rainfall and high intensity of light demonstrated this features. Populations from Katsina (smaller stomatal length in adaxial surface, lowest stomatal index in adaxial surface and smallest stomatal length in abaxial), Yobe (smaller stomatal length in adaxial surface, smallest stomatal width in adaxial surface and smallest stomatal size in adaxial surface), Kabba (lowest stomatal density on adaxial surface, smallest stomatal width, lowest stomatal index in abaxial surface and smallest stomatal size) and Sobi (smallest stomatal length in abaxial surface) have demonstrated these features than the populations from the Southern parts of the country where the annual amount of rainfall is relatively higher with high humidity and low temperature.

However, there are some exceptional cases that deviate from this pattern. Notable among these are populations from Maiduguri (with highest stomatal density in abaxial surface, widest stomatal width in both abaxial and adaxial surfaces and largest stomatal size also in abaxial surface), Kaiama big (with highest stomatal density in adaxial surface), Kabba (longest stomatal length in both abaxial and adaxial surfaces), Yobe (highest stomatal index in both abaxial and adaxial surfaces). This may be as a result of the shapes of the leaves which are erect with no particular leaf surface, facing the sun directly. The temperatures of these regions are high (Figure 01).

Another environmental factor that likely influenced the behaviour of stomatal features is carbon dioxide. However, unlike the response to the drought and temperature, stomatal response to elevated $\mathrm{CO}_{2}$ had contrasting results, varying from a decrease in SD (Lin et al., 2001; Woodward and Kelly, 1995) to a lack of stomatal acclimation within a single generation in wheat (Triticumaestivum L.) and sour oranges (Citrus aurantium L.) (Estiarte et al.,1994). This may also be responsible for some exceptional cases observed in the northern and southern populations of the Dipcadi filamentosum studied. In a study conducted on the influence of $\mathrm{CO}_{2}$ concentration on $\mathrm{SD}$ of several species grown in controlled environment, Woodward and Kelly (1995) found that changes in SD were generally greater in samples from amphistomatous species than 
those from hypostomatous species, such as pecan. This indicates that certain species may not show plasticity to environmental changes in a single generation for some eco-geographical traits. Though, the species studied in this work are amphistomatous, it followed similar pattern as described above.

Occurrence of more stomata in the lower or abaxial epidermal surface was majorly observed in majority of the populations across the 4 ecogeographical locations. Most plant species restricted their stomata to the lower surface in other to conserve water or reduce transpiration (AbdulRahaman and Oladele, 2009; Saadu et al., 2009). This phenomenon may have little or no significance in this species of Dipcadi where leaves are erected with no particular leaf surface facing the sun directly. The implication of this is that even the populations from the Southern part that should have epiamphistomatic leaves instead have hypoamphistomatic leaves and unexpectedly, the populations of Kabba and Tanke are equipped with more stomata in the upper surface than in the lower surface.

Significant differences were observedin the stomatal features within and among the populations of the D. filamentosum from different eco-geographical locations. Even though there is such significance differences among the populations collected at the same and different locations, there is no clear demarcation between populations from the 4 eco-geographical locations. This is supported by the clustering of the population from north east and south west as close neighbours, likewise the populations from north central with the north east. For instance, the abaxial stomatal density of Maiduguri, Kabba and Sobi populations were not significantly different from the populations from Ogun and Ekiti at $\mathrm{p}<0.05$. Also, the adaxial stomatal length of seven (7) populations across the 4 eco-geographical locations showed no significant differences namely Maiduguri, Katsina, Yobe, Oyo, Ogun, Katsina and Kabba. Noteworthy is closeness of populations from
Maiduguri and Ekiti in term of their stomatal density, length and width where there are no significant differences. Taking a clue from Masle et al., (2005) it is of great interest to understand the extent of plasticity of the ecogeographical traits to determine the stability and the possible use of the traits in breeding. In Arabidopsis thaliana (L.) Heynh., SD has been linked to mechanisms of instantaneous water use efficiency (transpiration efficiency), indicating the importance of the trait for plant survival in drought conditions (Masle et al., 2005).

The density of epidermal cells were generally higher in all the populations of Northern zones (North East, North Central and North West) than the populations of South West except in the Yobe populations which have the lowest epidermal cell density in both abaxial and adaxial surfaces. Meanwhile, it is only the Yobe populations that correlated the earlier reports on the size of the epidermal cells. Previous works reported that smaller cells should maintain turgor to lower values of water potential than larger cells. Rather larger changes in cell water relations are predicted for small changes in cell size. This prediction supports the hypothesis that plants or tissues with the smaller cell size will be more tolerant of low water potential (Ainsworth et al., 2006; Muller et al., 2007; Rymen et al., 2007; Tompson 2008; Weijschede et al., 2008).

\section{CONCLUSION}

In conclusion, the stability of certain leaf anatomical characteristics, such as stomatal density, index and size, for $D$. filamentosumpopulations grown at different locations confirms that environmental factors have little or no effect on these stable traitsand hence can be used for screening ecotypes and provenances for breeding and cultivar development.Since the plant used in this study were subjected to the same treatments 
and environmental conditions, the variations observed in leaf epidermal features are genetic variations which were induced by the selective pressures of the natural environments from which the populations were originally collected. Going by the results obtained from this work, it translates to mean that the environmental influence on the geographical distributions on the stomatal features and the epidermal cell number of the populations of $D$. filamentosum in Nigeria is partial and not total, and therefore can be used to separate them into different species.

\section{REFERENCES}

AbdulRahaman, A.A. and Oladele, F.A. (2003). Stomatal complex types, stomatal size, density and index in some vegetable species in Nigeria. Nigerian Journal of Botany. 16: pp. 144 150.

AbdulRahaman, A.A. and Oladele, F.A.(2009). Stomatal features and humidification potentials of Borassusaethiopum, Oreodoxaregia and Cocosnucifera. African Journal of Plant Science.3: pp. $059-063$.

Ainsworth, E.A., Rogers, A., Vodkin, L.O., Walter, A. and Schurra, U.(2006). The effects of elevated $\mathrm{CO}_{2}$ concentration on soybean gene expression. An analysis of growing and mature leaves. Plant Physiology.142: pp. 135 - 147. http://dx.doi.org/10.1104/pp.106.086256 PMid:16877698 PMCid:PMC1557602

Casson, S. and Gray, J.E. (2008). Influence of environmental factors on stomatal development. New Phytologist. 178: pp. 9 - 23. http://dx.doi.org/10.1111/j.1469-8137.2007.02351.x PMid:18266617

Dilcher, D.L.(1974). Approaches to the identification of Angiosperm Leaf remains. Botanical Review. 40: pp. 1-57. http://dx.doi.org/10.1007/BF02860067

Estiarte M, Penuelas J, Kimball BA, Idso SB, LaMorte RL, Pinter PJJr, Wall GW and Garcia RL 1994 Elevated $\mathrm{CO}_{2}$ effects on stomatal density of wheat and sour orange trees. Journalof Experimental Botany. 45: pp. 1665-1668. http://dx.doi.org/10.1093/jxb/45.11.1665

Franco, C.(1979). Relation between chromosome number and stomata in Coffee. Botanic Gazette. 100: pp. 817 - 818. http://dx.doi.org/10.1086/334832

Franks, P. J. and Farquhar, G.D.(2001). The effect of exogenous abscisic acid in stomatal development, stomatal mechanisms, and leaf gas exchange in Tradescantiavirginiana. Plant Physiology.125:935-942. http://dx.doi.org/10.1104/pp.125.2.935 PMid:11161050 PMCid:PMC64894

Ghazanfar, S.A. (1996). The Genus Dipcadi (Hyacinthaceae) in the Arabian Peninsula. Kew Bulletin. 51: pp. 803. http://dx.doi.org/10.2307/411973

Grey-Wilson, C. and Mathew, B.(1981).Bulb: the bulbous plants of Europe and their allies. Collins,London, UK. pp. 116. 
Jarvis, A. J. and Davies, W. J. (1998). The coupled response of stomatal conductance to photosynthesis and transpiration.Journal of Experimental Botany. 49: pp. 399-406. http:// dx.doi.org/10.1093/jexbot/49.suppl_1.39

Jones HG 1998 Stomatal control of photosynthesis and transpiration.Journal of Experimental Botany. 49: pp. 387-398. http://dx.doi.org/10.1093/jexbot/49.suppl_1.387

Kakani, V.G., Reddy, K. R., Zhao, D. and Mohammed, A.R.(2003). Effects of ultraviolet-b radiation on cotton (Gossypiumhirsutum L.) morphology and anatomy. Annals of Botany. 91: pp. 817826. http://dx.doi.org/10.1093/aob/mcg086 PMid:12770842 PMCid:PMC4242390

Kleinhenz, M. D., Bamberg, J.B. and Palta, J.P.(1995). Use of stomatal index as a marker to screen backcross populations of two wild potato species segregating for freezing tolerance. American Journal of Potato. 72: pp. 243-250. http://dx.doi.org/10.1007/BF02855039

Lake, J.A., Quick, W.P., Beerling, D.J. and Woodward, E.I.(2001). Signals from mature to new leaves. Nature. 411: pp. 154. http://dx.doi.org/10.1038/35075660 PMid:11346781

Lin, J., Jach, M.E. and Ceulemans, R.(2001). Stomatal density and needle anatomy of scots pine (Pinussylvestris) are affected by elevated $\mathrm{CO}_{2}$. New Phytologist. 150: pp. 665-674. http:// dx.doi.org/10.1046/j.1469-8137.2001.00124.x

Manning, J.C., Goldblatt, P. and Fay, M.F.(2004). A revised generic synopsis of Hyacinthaceae in Sub-Saharan Africa, based on molecular evidence, including new combinations and the new tribe Pseudoprospereae. Edinburgh Journal of Botany 60: pp. 533-568.

Masle, J., Gilmore, S.R. and Farquhar, G.D.(2005). The ERECTA gene regulates plant transpiration efficiency in Arabidopsis. Nature. 436: pp. 866-870. http://dx.doi.org/10.1038/nature03835 PMid:16007076

Metcalfe, C.R. and Chalk, L.(1988). Anatomy of Dicotyledon. (eds) .Oxford University Press,Oxford, UK. pp. 97-117.

Muller, B., Bourdais, G., Reidy, B., Bencivenni, C., Massonneau, A., Condamine, P., Rolland, G., Conejaro, G., Rogowskz, P. and Tardieu, F.(2007). Association of specific expansions with growth in maize leaves is maintained under environmental, genetic, and developmental sources of variation. Plant Physiology. 143: pp. 278 - 290. http://dx.doi.org/10.1104/ pp.106.087494

Nayeem, K.A.(1989). Genetic and environmental variation in stomatal frequency and distribution in wheatTriticum spp. Cereal Research Communications. 17: pp. 51-57.

Obiremi, E.O. and Oladele, F.A.(2001). Water conserving stomatal system in selected Citrus species. South African Journal of Botany. 67: pp. 258 - 260. http://dx.doi.org/10.1016/ S0254-6299(15)31127-3

Oyeleke, M. O, AbdulRahaman, A. A. and Oladele, F.A.(2004). Stomatal anatomy and transpiration rate in some afforestation tree species. Nigeria Society of Experimental Biology Journal. 4: pp. $83-90$. 
Rymen, B., Fioran,i F., Kartal, F., Vandepoele, K., Inze, D. and Beemster, G.T.S.(2007). Cold nights impair leaf growth and cell cycle progression in maize through transpirational changes of cell cycle genes. Plant Physiology 143: pp. 1429 - 1438. http://dx.doi.org/10.1104/ pp.106.093948 PMid:17208957 PMCid:PMC1820914

Saadu, R.O., AbdulRahaman, A. A. and Oladele, F.A.(2009). Stomatal complex types and transpiration rates in some tropical tuber species. African Journal of Plant Science. 3: pp. $107-112$.

Sagaram, M., Lombardini, L. and Grauke, L.J.(2007). Variation in leaf anatomy of pecan cultivars from three ecogeographic locations. Journal of the American Society for Horticultural Science. 132: pp. $592-596$.

Schoch, P.G., Zinsou, C. and Sibi, M.(1980).Dependence of the Stomatal Index on Environmental Factors during Stomatal Differentiation in Leaves of Vignasinensis L. Journal of Experimental Botany. 31: pp. 1211-1216. http://dx.doi.org/10.1093/jxb/31.5.1211

Serna, L. and Fenoli, C.(2000). Stomatal development in Arabidopsis: how to make a functional pattern. Trends in Plant Science. 5: pp. 458-460. http://dx.doi.org/10.1016/S13601385(00)01782-9

Stace, C.A.(1965). Cuticular studies as an aid to plant taxonomy. Bulletin of the British Museum (National History) Botanical. 4: pp. 3 - 78.

Stevens, P.F.(2001). Angiosperm Phylogeny Website: Asparagales: Scilloideae, retrieved 201303-28.

Tompson, D.S.(2008). Space and time in the plant cell wall: relationships between cell type, cell wall rheology and cell function. Annals of Botany. 101: pp. 203 - 211. http://dx.doi. org/10.1093/aob/mcm138

Van Rensburg, L., Peacock, J. and Krueger, G.H.J.(1999). Boundary layer, stomatal geometry and spacing, in relation to drought tolerance in four Nicotianatabacum L. cultivars. South AfricanJournal Plant Soil 16: pp. 44-49. http://dx.doi.org/10.1080/02571862.1999.10634 844

Weijschede, J., Antonise, K., deCaluwe, H., deKroon, H. and Huber, H.(2008). Effects of cell number and cell size on petiole length variation in a stoloniferous herb. American Journal of Botany. 95: pp. 41 - 49. http://dx.doi.org/10.3732/ajb.95.1.41 PMid:21632313

Wilkinson, H.P. (1979). Leaf anatomy of various Anacardiaceae. Ph.D. Thesis, University of London, London.

Woodward, F. I. and Kelly, C.K.(1995). The influence of $\mathrm{CO}_{2}$ concentration on stomatal density. New Phytologist. 13: pp. 311-327. http://dx.doi.org/10.1111/j.1469-8137.1995.tb03067.x 